\title{
ALIEN SPECIES OF EU CONCERN IN ROMANIA
} \author{
Paulina ANASTASIU *, Cristina PREDA **,Doru BĂNĂDUC *** and Dan COGĂLNICEANU ** \\ * University of Bucharest, Department of Botany and Microbiology and Botanic Garden "D. Brândza", \\ Intrarea Portocalelor 1-3, Bucharest, Romania, RO-060101, paulina.anastasiu@bio.unibuc.ro \\ ** "Ovidius" University of Constanţa, Faculty of Natural Sciences and Agricultural Sciences, Aleea \\ Universităţii 1, corp B, Constanţa, Constanţa County, Romania, RO-900470, cristina.preda@univ- \\ ovidius.ro, dcogalniceanu@univ-ovidius.ro \\ *** "Lucian Blaga" University of Sibiu, Applied Ecology Research Center, Dr. Ion Raţiu Street 5-7, \\ Sibiu, Sibiu County, Romania, RO-550012, doru.banaduc@ulbsibiu.ro, ad.banaduc@yahoo.com
}

DOI: 10.1515/trser-2017-0024

KEYWORDS: alien species, Romania, distribution, invasiveness, EU list.

\section{ABSTRACT}

Of the 37 species of the European Union concern eight are already present and two present a future potential risk for Romania. This paper brings updated information regarding these species in Romania. The presence of eight invasive alien species of concern to the European Union have already been recorded in Romania: two plant species Cabomba caroliniana and Heracleum sosnowskyi, two crustaceans Orconectes limosus and Eriocheir sinensis, two fish species Pseudorasbora parva and Perccottus glenii, one reptile Trachemys scripta and one mammal Myocastor coypus. Other two species of Union concern (Lithobates catesbeianus and Procyon lotor) may soon become invaders in Romania. We emphasize the urgent need to assess their current distribution and impact or potential to establish and possible impact at national level.

RÉSUMÉ: Espèces exotiques préoccupantes pour l'Union Européenne en Roumanie.

Parmis les 37 espèces préoccupantes pour l'Union Européenne, huit sont déjà présentes et deux autres présentent un futur risque potentiel pour la Roumanie. Cet article apporte des informations régulièrement mise à jour sur ces espèces en Roumanie. La présence de huit espèces exotiques envahissantes préoccupantes pour l'Union a été déjà notée pour la Roumanie: deux espèces végétales Cabomba caroliniana et Heracleum sosnowskyi, deux crustacés Orconectes limosus et Eriocheir sinensis, deux espèces de poissons Pseudorasbora parva et Perccottus glenii, un reptile Trachemys scripta et un mammifère Myocastor coypus. Deux autres espèces préoccupantes pour l'Union (Lithobates catesbeianus et Procyon lotor) deviendront bientôt des espèces envahissantes en Roumanie. Nous insistons sur le besoin urgent d'évaluer au niveau national leur distribution et leur impact présent ou leur capacité à s'installer et leur impact possible.

REZUMAT: Specii alogene de interes pentru Uniunea Europeană.

Dintre cele 37 specii care preocupă Uniunea Europeană, opt sunt deja prezente și două prezintă un viitor risc potențial pentru România. Prezentul articol aduce informații actualizate cu privire la aceste specii în România. Prezența a opt specii invazive alogene de interes pentru Uniune a fost deja înregistrată în România: două specii de plante Cabomba caroliniana și Heracleum sosnowskyi, două specii de crustacee Orconectes limosus și Eriocheir sinensis, două specii de pești Pseudorasbora parva și Perccottus glenii, o specie de reptile Trachemys scripta și o specie de mamifere Myocastor coypus. Două alte specii de interes pentru UE (Lithobates catesbeianus și Procyon lotor) vor deveni în curând specii invazive în România. Insistăm asupra nevoii urgente de evaluare a distribuției și impactului acestora în prezent sau a potențialului de a se stabili și a posibilului impact la nivel național. 


\section{INTRODUCTION}

Any regional flora and fauna goes through continuous changes yet these changes are, most of the time, difficult to perceive during a human lifetime. Some natural phenomena such as volcanic eruptions, glaciations, meteorite impacts, etc., are accelerating the flora and fauna turn-over. After man's expansion on Earth, the changes in the structure of the flora and fauna occurred at an increasing pace, locally, regionally, and globally. The profound changes of the last decades under the influence of the industrialization and respectively of globalization include also a larger and increasingly worrying "fluidity" in the reduction, disappearance and introduction of species in equally more extensive biogeographical areas. Alien species and damage or loss of natural habitats are the main factors responsible for the disappearance of some species in past centuries. (Strahm and Rietbergen, 2001) Biodiversity conservation elements should include alien species assessment, monitoring, and management elements (Curtean-Bănăduc, 2006). Aquatic ecosystems, especially those already disturbed by various human activities, appear to be particularly vulnerable to these invasions (Lodge et al., 1998).

In July 2016, the EU adopted a list of 37 invasive alien species that are subject to the restrictions and measures set out in the EU Regulation 1143/2014. The list comprises 23 animals (six species of Crustacea, one insect, two fishes from Actinopterygii class, one amphibian, one reptile, three birds, nine mammals) and 14 plant species (Tab. 1) (European Comission, 2016).

As such, all member states are required to implement cost-effective measures to eradicate these species.

There are several major problems regarding the impact of alien species on biodiversity conservation and management at national level. Thus Romanian legislation on alien species (Ministerial Order 979/2009) does not include lists of alien species and refers to the DAISIE list. Also, the National Biodiversity Strategy and Action Plan 2014-2020 (https://www.cbd.int/doc/world/ro/ro-nbsap-v3-en.pdf) were not ratified by authorities, and the European Biodiversity Strategy 2020 is not implemented at the national level. To comply with the implementation of the EU Regulation 1143/2014, it is necessary to gather information regarding the presence of species of interest, and evaluate their introduction pathways, distribution, and invasive status. Difficulties are encountered in such initiatives: there is limited data available in the scientific literature, inconsistencies and errors in the available databases (e.g., CABI, DAISIE, NOBANIS), and lack of national databases and/or public information regarding alien species. Of the 37 invasive alien species of EU concern, 29 species were not yet reported in Romania, and also their invasion risk was not evaluated.

There is a scarcity of data regarding alien species where apart from the first recording in the country, detailed and updated distribution maps and surveys are missing. The goal of the present paper is to illustrate an update on the distribution and known impact of the alien species of EU concern present in Romania. 
Table 1: List of invasive alien species considered of European Union concern according to Commission Implementing Regulation (EU) 2016/1141.

\begin{tabular}{|c|c|c|}
\hline Kingdom & Class & Species \\
\hline Plantae & Magnoliatae & Baccharis halimifolia L. \\
\hline Plantae & Magnoliatae & Cabomba caroliniana Gray \\
\hline Animalia & Mammalia & Callosciurus erythraeus Pallas, 1779 \\
\hline Animalia & Aves & Corvus splendens Viellot, 1817 \\
\hline Plantae & Liliatae & Eichhornia crassipes (Martius) Solms \\
\hline Animalia & Crustacea & Eriocheir sinensis H. Milne Edwards, 1854 \\
\hline Plantae & Magnoliatae & Heracleum persicum Fischer \\
\hline Plantae & Magnoliatae & Heracleum sosnowskyi Mandenova \\
\hline Animalia & Mammalia & Herpestes javanicus É. Geoffroy Saint-Hilaire, 1818 \\
\hline Plantae & Magnoliatae & Hydrocotyle ranunculoides L. f. \\
\hline Plantae & Liliatae & Lagarosiphon major (Ridley) Moss \\
\hline Animalia & Amphibia & Lithobates (Rana) catesbeianus Shaw, 1802 \\
\hline Plantae & Magnoliatae & Ludwigia grandiflora (Michx.) Greuter and Burdet \\
\hline Plantae & Magnoliatae & Ludwigia peploides (Kunth) P. H. Raven \\
\hline Plantae & Liliatae & Lysichiton americanus Hultén and St. John \\
\hline Animalia & Mammalia & Muntiacus reevesi Ogilby, 1839 \\
\hline Animalia & Mammalia & Myocastor coypus Molina, 1782 \\
\hline Plantae & Magnoliatae & Myriophyllum aquaticum (Vell.) Verdc. \\
\hline Animalia & Mammalia & Nasua nasua Linnaeus, 1766 \\
\hline Animalia & Crustacea & Orconectes limosus Rafinesque, 1817 \\
\hline Animalia & Crustacea & Orconectes virilis Hagen, 1870 \\
\hline Animalia & Aves & Oxyura jamaicensis Gmelin, 1789 \\
\hline Animalia & Crustacea & Pacifastacus leniusculus Dana, 1852 \\
\hline Plantae & Magnoliatae & Parthenium hysterophorus L. \\
\hline Animalia & Actinopterygii & Perccottus glenii Dybowski, 1877 \\
\hline Plantae & Magnoliatae & Persicaria perfoliata (L.) H. Gross (Polygonum perfoliatum L.) \\
\hline Animalia & Crustacea & Procambarus clarkii Girard, 1852 \\
\hline Animalia & Crustacea & Procambarus fallax (Hagen, 1870) f. virginalis \\
\hline Animalia & Mammalia & Procyon lotor Linnaeus, 1758 \\
\hline Animalia & Actinopterygii & Pseudorasbora parva Temminck and Schlegel, 1846 \\
\hline Plantae & Magnoliatae & Pueraria montana (Lour.) Merr. (Willd.) Pueraria lobata (Willd.) \\
\hline Animalia & Mammalia & Sciurus carolinensis Gmelin, 1788 \\
\hline Animalia & Mammalia & Sciurus niger Linnaeus, 1758 \\
\hline Animalia & Mammalia & Tamias sibiricus Laxmann, 1769 \\
\hline Animalia & Aves & Threskiornis aethiopicus Latham, 1790 \\
\hline Animalia & Reptilia & Trachemys scripta Schoepff, 1792 \\
\hline Animalia & Insecta & Vespa velutina nigrithorax de Buysson, 1905 \\
\hline
\end{tabular}




\section{MATERIAL AND METHODS}

Information regarding distribution and potential impact of the target species was collected from many sources. The authors added to their personal field data, information based on reliable personal communications, literature and databases (CABI ISC, DAISIE, ESENIAS, GISD), questionnaires for game species managers, surveys of pet-shops and field surveys, etc. The data about the distribution and introduction pathways were collected from many reference data. The invasive status was considered (high, medium, low) based on expert opinion.

\section{RESULTS AND DISCUSSION}

The 37 invasive alien plant and animal species of EU concern are distributed among the following higher taxa: three Liliatae, 11 Magnoliatae, six Crustacea, one Insecta, two Actinopterygii, one Amphibia, one Reptilia, three Aves, and nine Mammalia.

\section{Plants}

In regards to alien plant species, 14 are included on the list of EU concern, but only two have so far been found in Romania: Cabomba caroliniana and Heracleum sosnowskyi (Anastasiu and Negrean, 2009; Sîrbu and Oprea, 2011). Both are considered naturalized. One location has been reported for both species, but the data are very old and need to be updated.

Cabomba caroliniana A. Gray (family Cabombaceae) (Carolina water-shield) originates from America. In Romania it was acclimatized in the Ochiul Tiganilor Wetland and Pârâul Pețea near Băile 1 Mai (Bihor County) in 1950 (Ţopa, 1955). This is the single presence point of this plant known in Romania. Țopa (1955) specifies that it is a beautiful plant and can be easily reproduced by cuttings, and is recommended for freshwater aquariums. The plant has been recently reported as naturalized in Romania (Lansdown et al., 2016), without any further information being provided about its distribution. Its invasion risk in Romania is medium.

The species is not included in Flora Europaea, even though the data reported from Romania preceded the publication of the two editions of Flora Europaea. Uotila (2009) indicates it as a foreign species only in Great Britain (Sîrbu and Oprea, 2011). According to the file available at www.cabi.org, Cabomba carolianiana is present only in the following European states: Belgium, France, Greece, Hungary, the Netherlands, Serbia, United Kingdom (England, Scotland, and Wales).

The second plant species of interest for this paper is Sosnowskyi's hogweed (Heracleum sosnowskyi Manden., Apiaceae).

According to the file available at www.cabi.org, Heracleum sosnowskyi is present in the following European states: Belarus, Denmark, Estonia, Finland, Germany, Hungary, Iceland, Latvia, Lithuania, Poland, Russia, Ukraine. Romania is not featured on this list, although the plant was reported as naturalized in 2001 (Maruşca and Pop, 2001) and is included on the list of neophytes in Romania (Anastasiu and Negrean, 2009). According to Maruşca and Pop (2001), the species was brought to Romania from Poland in 1975, during a presidential visit, whereby it was presented as high quality fodder. Initially cultivated at Fundulea (Călăraşi County), in 1980 it was transferred to Prejmer (Braşov County). The plant did not survive at Fundulea, but it did survive at Prejmer, although in the first years it was small and it did not show any tendency to expand. Twenty years after its introduction in Braşov County, Heracleum sosnowskyi was found approximately 300 meters away from the place where it was first sown, nearby Halta Ilieni, with over 900 individuals on a surface of around $750 \mathrm{~m}^{2}$ (Maruşca and Pop, 2001). The two authors consider that Heracleum sosnowskyi is "an invasive and dominant species" which forms a new vegetal association, Cirsio (oleracei) - Heraclietum. According to Maruşca and Pop (2001), "the dominant species - Heracleum 
sosnowskyi, eliminated almost all the other species. Considering its continuing expansion, this species could represent a real danger for zonal biodiversity as well as for a large area biodiversity." Nevertheless, subsequent data regarding the expansion and impact of this species have not been published. The invasion risk of $H$. sosnowskzi in Romania is high.

In regards to Eichhornia crassipes, another species of interest for the European Union, the species is not mentioned in older papers, but it is recorded as casual in a more recent paper (Lansdown et al., 2016). It constantly enters the country due to horticulture trade.

\section{Invertebrates}

The List of EU concerns contains seven invertebrate species, of which six are aquatic, represented by crustaceans, and one is a terrestrial insect. The presence of two of these invertebrate species, namely Orconectes limosus and Eriocheir sinensis, have previously been recorded in Romania in natural and semi-natural habitats. However, their status and current distribution need to be updated, and the potential impact of the species should also be assessed.

The spiny-cheek crayfish, Orconectes limosus, is native to North America and was intentionally introduced in Europe in the late 19th century possibly to compensate for the decline of the native noble crayfish Astacus astacus (L.) populations (Holdich, 2002; Holdich and Black, 2007). The species is currently widespread in Europe, expanding its range naturally as well as through human-mediated dispersion. In Romania, O. limosus was first recorded in spring 2008 on the shore of the Danube in an area included in the Iron Gates Natural Park (located in SW Romania) and is quickly spreading downstream at an estimated rate of 13-16 $\mathrm{km} \mathrm{yr}^{-1}$ (Pârvulescu et al., 2009). O. limosus competes with native species for resources and it may have an impact on the structure of the invaded habitats (Gherardi, 2007). But it is also involved in the transmission of the "crayfish plague" to native species, a disease caused by infection with the oomycete Aphanomyces astaci that is considered a major contributor to the decline of European freshwater crayfish (Schrimpf et al., 2012). The invasion risk of $O$. limosus was evaluated as high.

Following the accidental introduction in Germany in 1912 from its native range in eastern Asia, the Chinese mitten crab, Eriocheir sinensis, has spread throughout Europe (Herborg et al., 2003). The presence of E. sinensis was first recorded in Romania in the late 90's (Gomoiu and Skolka, 1998) and subsequently in the Danube Delta (Oțel, 2004; Micu and Micu, 2006). The species is probably found along the entire lower sector of the Danube, as it has been observed in several locations in Serbia (Paunovic et al., 2004; Škraba et al., 2013) and Bulgaria (Kutsarov and Trichkova, 2016). However, the Chinese mitten crab is a catadromous species. The adults migrate to brackish or salt waters to reproduce while the juvenile crabs invade estuaries during their migration upstream and they can travel great distances (i.e. hundreds of $\mathrm{km}$ ). According to Herborg et al. (2003), the average total distance of upstream migration reached $562 \mathrm{~km} /$ year during the peak period 1928-1939 for Northern Europe and 104 km/year for Southern France (1954-1960). The Chinese mitten crabs are omnivorous and may negatively affect native communities through e.g. competition, predation, and nutrient cycling. Rudnick and Resh (2005) suggest that E. sinensis feeding habits could influence shifts in the composition of the invertebrate communities towards deeper sedimentdwelling species and that the crabs have an impact on nutrient dynamics as they export biomass out of the freshwater ecosystems when migrating for reproduction. The Chinese mitten crabs can cause riverbank erosion through their burrowing activities. Recently, the Chinese mitten crabs have been identified as vectors of the crayfish plague pathogen Aphanomyces astaci (Schrimpf et al., 2014). The invasion risk of E. sinensis is high. 
The other five invertebrate species included in the List of Union concern have not been recorded in Romania yet, but their arrival might be just a matter of time. The red swamp crayfish, Procambarus clarckii, and the signal crayfish, Pacifastacus leniusculus, are known to occur in several European countries while the virile crayfish, Orconectes virilis, and the marbled crayfish, Procambarus fallax, have a more restricted distribution (Kouba et al., 2014; Loureiro et al., 2015). Nevertheless, P. leniusculus has been observed in Hungary since the 2000’s (Puky et al., 2005) and further expansion coupled with intentional releases or escapees from the aquarium/aquaculture trade increases the chances that various alien crayfish establish in natural and semi-natural habitats. Their impact on native biota and ecosystems can occur through a wide range of mechanisms, like in the case of the red swamp crayfish (SoutyGrosset et al., 2016).

The Asian yellow-legged hornet, Vespa velutina, is the only insect currently on the list. In 2004, the subspecies nigrithorax was recorded in south-western France (Haxaire et al., 2006) and subsequently spread to other European countries, including Italy (Bertolino et al., 2016). Recent studies suggest that $V$. velutina could spread over a large part of Europe, and that climate change increases the risk of invasion (Rome et al., 2011; Barbet-Massin et al., 2013). As a predator of other insects, particularly the honey bee, the presence of $V$. velutina in Europe causes concern related to its potential impact on bee colonies and pollination, beekeeping, and human health (de Haro et al., 2010; Monceau et al., 2013; Arca et al., 2014). We consider monitoring actions and awareness campaigns mandatory for the early detection of these and other alien species in order to prevent their spread and impact at lowest costs.

\section{Amphibians and reptiles}

The American Bullfrog (Lithobates catesbeianus) was introduced in several western European countries (France, Italy, Belgium, United Kingdom, Spain) (Stumpel, 1992), but is still scarcely distributed in Eastern Europe: it was only reported from the island of Krete (Ficetola et al., 2007a) and recently from Slovenia (Kirbiš et al., 2016), although the region overall has a high suitability for the species (Ficetola et al., 2007b). There are no distribution records from Romania or its neighbouring countries, although there is a risk of introduction by farming or the pet trade.

The Common Slider, Trachemys scripta, is the most widespread alien species in the region, and reports of successful breeding populations are available from several European countries including: Italy (Crescente et al., 2014), Serbia (Đorđević and Anđelković, 2015), Slovenia (Vamberger et al., 2012), Croatia (Jelić et al., 2016), and southern Turkey (Çiçek and Ayaz, 2015). Juveniles are still traded in pet-shops. The presence of this species in Romania was reported only from ponds and lakes within urban areas or their vicinities. Due to its longevity, it can achieve high population densities (Ficetola et al., 2012). It can compete with the native terrapin (Emys orbicularis) for resources, can transmit parasites and pathogens, and is a predator of native freshwater fauna. The invasion risk of $T$. scripta is evaluated as medium.

\section{Fish}

Among the vertebrates, the freshwater fish species have the largest share in the accidental and by-purpose introductions of alien species. In most of these cases, a negative direct and indirect impact was registered on the native species. In Europe, there are about 40 introduced fish species, and many more were translocated from some other European countries. In most cases a foreign species of fish will not be limited to the basin of initial entry; most often that species will spread into an increasingly expanded territory (Holčik, 1991). 
Among the fish species listed by the EU in this study context, Pseudorasbora parva is widespread in Romania in the last decades, and Perccottus glenii is in a constant trend of increasing its distribution. The potential impact of both of these species should be assessed.

Pseudorasbora parva Temminck and Schlegel, 1846 (Actinopterygii, Cypriniformes, Cyprinidae, Gobininae) it is a freshwater, benthopelagic, small-sized fish $(7-12 \mathrm{~cm})$, most abundantly found in well vegetated small channels and ponds and lakes but also in running water, maximum reported age five years fish species with a relatively large distribution: Amur to Zhujiang drainages in Siberia, Korea and China. Introduced in various areas in Asia and Europe, several countries reported adverse ecological impact after introduction. It feeds on small insects, fish and fish eggs, and usually breeds in habitats with still or very slow-flowing water three-four times in a season. (Bănărescu, 1964; Bănărescu and Nalbant, 1965, 1973; Welcomme, 1988; Bănărescu, 1990; Novikov et al., 2002; Bănăduc and Bănăduc, 2008; Verreycken et al., 2011) The invasion risk of $P$. parva was evaluated as high.

$P$. parva, was accidentally introduced from Yang-Tze Watershed from China in Romania (Nucet, Dâmbovița and Cefa, Bihor piscicultural stations for aquaculture) in 19601962, together with the Chinese cyprinids with economic value (Ctenopharyngodon idella Cuvier and Valenciennes, 1848, Hypophthalmichthys molitrix Cuvier and Valenciennes, 1848, Aristichthys nobilis (Richardson, 1844), Mylopharyngodon piceus (Richardson, 1846), Parabramis pekinensis (Basilewsky, 1855), Megalobrama terminalis (Richardson, 1846)) (Witkowski, 2009)

$P$. parva is a species with a high dispersion potential, which succeeded in spreading out in almost all the countries of Europe during the 45 years that passed from its admission into this continent. There were several centers in Europe, out of which the P. parva then spread out on almost the entire continent. The two major centers were Romania (from where the species naturally spread out in the whole Danube Basin) and Albania (from where the species spread out in the Balkans, still naturally). In the countries of the former Yougoslavia, the species penetrated from both centers; in Hungary, Slovakia and the Czech Republic, the species penetrated naturally, and from Romania, it penetrated artificially, as it was brought straight from China together with some other species of fish of economic interest. In Poland and Northern Bulgaria, the species was seemingly brought from the Ukraine. The origin of the populations in Italy and France is unknown, but these populations probably come from the Danube Basin. We assume that the species arrived in Denmark from Germany. We do not know how the species got on England's and Spain's territory, but it was most likely artificially introduced from a European country. (Gavriloaie, 2007)

In Romania and surrounding countries P. parva is living already in the Danube River and all the Romanian hydrographic basins: Tisa, Someş, Crişuri, Mureş, Bega, Timiş, Caraş, Miniş, northern Danube Iron Gorge tributaries, Cerna, Jiu, Olt, Vedea, Argeş, Ialomiţa, Mostiştea, Călmăţui, Siret, Prut, and in some of the near Black Sea Dobrogea region water bodies (Giurcă and Angelescu, 1971; Bănăduc, 1999, 2005, 2013; Schiemer et al., 2004; Battes et al., 2005; Oţel, 2007; Hartel et al., 2007; Costiniuc et al., 2006; Moşu et al., 2006; Năvodaru and Năstase, 2006; Vornicu et al., 2006; Ardelean and Wilhelm, 2007; Telcean and Cupşa, 2009; Goia et al., 2014; Ureche and Ureche, 2015; Bănăduc et al., 2016; Takács et al., 2017).

The appreciable dispersal of $P$. parva on the Romanian hydrographical basins, after its accidental introduction, was due to escapes from piscicultural basins and in their adjacent channels and streams and rivers, and its use as living bait. 
It thrives in piscicultural and in the natural areas in some lakes and small hill- and plain- rivers, but is also present in large rivers and even lakes. The polluted areas are included in its normal range of distribution (Gavriloaie and Chiş, 2006).

In the background of the intensive trade of Chinese carp species in 1960s, the invasive characteristics of this accidental introduced fish species with a high plasticity and adaptability to lentic and lotic conditions were proved extensively through natural dispersal in the Romanian hydrographical net. The potential management actions are severely limited to early detection and rapid intervention.

A climatic and human impact associated model combined with an introduction pathways analysis could enable accurate prediction on the risk of spread of this species areal in the higher altitude Romanian water bodies, allowing for robust monitoring and fast intervention management actions.

Perccottus glenii Dybowski, 1877 (Actinopterygii, Perciformes, Odontobutidae) is a freshwater, brackish, demersal, fish species that occurs in lentic waters, lakes, ponds, backwaters and marshes with dense underwater vegetation. It avoids lotic sectors with currents, can tolerate poorly oxygenated water, and is able to survive in dried out or completely frozen water bodies by digging itself into mud where it hibernates. Maximum reported age is seven years for this fish species, and it has a large distribution. The Sea of Okhotsk and Amur southward to Yangtze and Fujian is included in its distribution. It was introduced in Europe, and at least one country reports adverse ecological impact after introduction. It is a voracious predatory fish, feeds on invertebrates, tadpoles and fish, posing a most serious threat to aquatic fauna wherever it occurs, in small water bodies known to extirpate almost all other fish species and amphibian larvae. Reproduction starts for the first time at one-three years, with males guarding the eggs and pelagic larvae (Berg, 1965; Novikov et al., 2002; Koščo et al., 2008; Kati et al., 2015). The invasion risk of $P$. parva was evaluated as moderate to high.

P. glenii was introduced in Russia, near Sankt Petersburg at the beginning of the 20th century, and only later, during the past two decades, it started spreading to the west of Europe. Because of its high resistance to extreme environmental conditions and due to the economic loss caused in the fishing ponds, this species became a real threat for the freshwater ecosystems in Asia and Europe. (Luca and Ghiorghiţă, 2014)

Perccottus glenii appeared recently and spread in different parts of the Romanian and neighboring countries' watersheds like: Danube Delta, Danube River, Mureş River basin, Siret Basin, Suceava Basin, Crişuri rivers basin and Timiş River basin (Nalbant et al., 2004; Jurajda et al., 2006; Simonović et al., 2006; Popa et al., 2006; Moşu, 2007; Năstase, 2007; CopilaşCiocianu and Pârvulescu, 2011; Covaciu-Marcov et al., 2011; Kvach, 2012; Luca et al., 2014; Bănăduc et al., 2016; Telcean and Cicort-Lucaciu, 2016; Takács et al., 2017).

\section{Birds}

None of the alien bird species of Union concern have been reported in Romania, but their presence should be carefully monitored due to the rapid expansion of their range.

\section{Mammals}

Nine mammalian alien species are of Union concern, of which only Myocastor coypus is present in Romania. Procyon lotor might soon become an invader as it is already present in neighbouring countries.

Myocastor coypus, is a large, robust and heavy rat-like rodent, with an average body weight of five-six $\mathrm{kg}$, with males bigger than females reaching up to $10 \mathrm{~kg}$ (Bertolino et al., 2012). Coypus are mostly nocturnal, inhabiting aquatic habitats where they feed on vegetation 
(Wood et al., 1992). Originating from southern South America, it was introduced in Europe for the fur trade, starting in the 1880's in France (Carter and Leonard, 2002). It is now established in Europe. It was first reported in Romania in 1959 (Murariu and Chișamera, 2004). It has an impact on bank stability due to its burrows; it can impact aquatic vegetation through overgrazing and can prey on the water birds nests (Woods et al., 1992; Angelici et al., 2012). The $M$. coypus presents a high invasion risk for Romania.

A climatic and human impact associated model combined with an introduction pathways analysis could enable accurate prediction on the risk of more extention of this fish species areal in the unaffected by now of Romanian water bodies, allowing for robust monitoring and fast intervention management actions.

\section{CONCLUSIONS}

Are the identified data up to date? Is their updating necessary before setting the management measures for these particular species? What are the entry paths? What is the invasiveness status in our country?

The data available so far are not sufficient for developing an adequate management plan for the control, containment, and eradication of these species. A national program to monitor the distribution and impact of these species is required, together with the development of a rapid response and information network of the countries in the region. The pet and horticultural trades require strict regulations regarding the import of species posing high risk of invasiveness, since the most unregulated activities are the pet trade and the horticulture trade.

The studied alien species of interest for the European Union present in Romania were partially reported, the most of them with medium to high invasion risk, yet their present distribution is not known.

\section{ACKNOWLEDGEMENTS}

This paper was realised in the context of the characteristic activities of East and South European Network for Invasive Alien Species (ESENIAS), Danube Region Invasive Alien Species Network (DIAS), and International Association for Danube Research (IAD). A special thanks to our colleague Trichkova T., for her continuous support.

\section{REFERENCES}

1. Anastasiu P. and Negrean G., 2009 - Neophytes in Romania, in Rakosy L. and Momeu L. (eds), Neobiota din România, Presa Universitară Clujeană, ISBN 978-973-610-923-2, 66-97.

2. Angelici C., Marini F., Battisti C., Bertolino S., Capizzi D. and Monaco A., 2012 Cumulative impact of rats and coypu on nesting water birds: First evidences from a small mediterranean wetland (Central Italy), Vie et milieu, Life and environment, 62, 3, 137-141.

3. Arca M., Papachristoforou A., Mougel F., Rortais A., Monceau K., Bonnard O., Tardy P., Thiéry D., Silvain J. F. and Arnold G., 2014 - Defensive behavior of Apis mellifera against Vespa velutina in France: Testing whether European honeybees can develop an effective collective defence against a new predator, Behavioural Processes, 106, 122-129.

4. Ardelean G. and Wilhelm S., 2007 - Polluting factors and their effects on the ichthyofauna of the Lăpuş Valley (Maramureş, Romania), Acta Ichtiologica Romanica, II, 17-24.

5. Barbet-Massin M., Rome Q., Muller F., Perrard A., Villemant C. and Jiguet F., 2013 Climate change increases the risk of invasion by the Yellow-legged hornet, Biological Conservation, 157, 4-10.

6. Battes K. W., Pricope F., Ureche D. and Stoica I., 2005 - Ichthyofauna status in the Siret catchment area, with emphasis on the effect of the January 2001 pollution, Analele Ştiinţifice ale Universităţii "Alexandru Ioan Cuza" Iaşi, Biologie animală, LI, 123-143. 
7. Bănăduc D., 1999 - Data concerning the human impact on the ichthyofauna of the upper and middle sectors of the Olt River, Transylvanian Review of Systematical and Ecological Research, 1, The Upper and Middle Olt River Basin, 157-164.

8. Bănăduc D., 2005 - Fish associations - habitats quality relation in the Târnave Rivers (Transylvania, Romania) ecological assessment, Transylvanian Review of Systematical and Ecological Research, 2, The Târnava River Basin, 123-136.

9. Bănăduc D., 2013 - The fish fauna of the Timiş River (Banat, Romania), Transylvanian Review of Systematical and Ecological Research, 15, The Timiş River Basin, 145-172.

10. Bănăduc A. and Bănăduc D., 2008 - Trophic elements regarding the non-indigenous Pseudorasbora parva (Schlegel) 1842 fish species spreading success - Olt River Basin, a case study, Journal of Biology - Zoology, 6, Edit. Academiei Române, 185-196.

11. Bănăduc D., Rey S., Trichkova T., Lenhardt M. and Curtean-Bănăduc A., 2016 - The Lower Danube River-Danube Delta-North West Black Sea: A pivotal area of major interest for the past, present and future of its fish fauna - A short review, Science of the Total Environment, 545-546, DOI: 10.1016/j.scitotenv.2015.12.05, 137-151.

12. Bănărescu P. M., 1964 - Fauna R. P. Române, Pisces-Osteichthyes, XIII, Edit. Academiei Române, 959. (in Romanian)

13. Bănărescu P., 1990 - Zur ausbreitungsgeschichte von Pseudorasbora parva in Südosteuropa (Pisces, Cyprinidae) (The spread of P. parva in the freshwaters of South-Eastern Europe), Revue Roumaine de Biologie - Série de Biologie Animale, 35, 13-16. (in German)

14. Bănărescu P. and Nalbant T., 1965 - Studies on the systematics of Gobioninae (Pisces, Cyprinidae), Revue Roumanie de Biologie - Série de Biologie Animale, 10, 219-228.

15. Bănărescu P. and Nalbant T., 1973 - Pisces, Teleostei. Cyprinidae (Gobioninae), Das Tierreich, Lief, 93 W, de Gruyter, Berlin, 304.

16. Berg L. S., 1965 - Freshwater fishes of the U.S.S.R. and adjacent countries, 3, 4th edition, Israel Program for Scientific Translations Ltd, Jerusalem. (Russian version in 1949).

17. Bertolino S., Guichón M. and Carter J., 2012 - Myocastor coypus Molina (coypu), in "Handbook of Global freshwater invasive species", 357-368.

18. Bertolino S., Lioy S., Laurino D., Manino A. and Porporato M., 2016 - Spread of the invasive yellow legged hornet Vespa velutina in Italy, Applied Entomology and Zoology, 51, 589-597.

19. Carter J. and Leonard B. P., 2002 - A review of the literature on the worldwide distribution, spread of, and efforts to eradicate the (Myocastor coypus), Wildlife Society Bulletin, 162-175.

20. Çiçek K. and Ayaz D., 2015 - Does the red-eared slider (Trachemys scripta elegans) breed in Turkey?, HYLA-Herpetološki bilten, 2015, 1, 4-10.

21. Copilaş-Ciocianu D. and Pârvulescu L., 2011 - New record of the Amur sleeper Perccottus glenii Dybowski, 1877, first record in the Mureş River Basin, Biharean Biologist, 5, 1, 73-74.

22. Costiniuc C. D., Davideanu G. and Davideanu A., 2006 - Data concerning the fish communities of the Jijia River (Romania), Acta Ichtiologica Romanica, I, 55-64.

23. Covaciu-Marcov S. D., Telcean I. and Ferenţi S., 2011 - Range extension of Perccotus glenii Dybowski, 1877 in Western Romania, a new distribution route in the Danube River Basin? Journal of Applied Ichthyology, 27, 144-145.

24. Crescente A., Sperone E., Paolillo G., Bernabò I., Brunelli E. and Tripepi S., 2014 - Nesting ecology of the exotic Trachemys scripta elegans in an area of Southern Italy (Angitola Lake, Calabria), Amphibia-Reptilia, 35, 3, 366-370.

25. Curtean-Bănăduc A., 2006 - Strategii şi metode de conservare a biodiversităţii, Edit. Alma Mater Sibiu, 202. (in Romanian)

26. de Haro L., Labadie M., Chanseau P., Cabot C., Blanc-Brisset I., Penouil F., National Coordination Committee for Toxicovigilance, 2010 - Medical consequences of the Asian black hornet (Vespa velutina) invasion in Southwestern France, Toxicon, 55, 650-652.

27. Đorđević S. and Anđelković M., 2015 - Possible reproduction of the red-eared slider, in Serbia, under natural conditions, HYLA-Herpetološki bilten, 2015, 1, 44-49. 
28. European Comission, 2016 - Commission Implementing Regulation (EU) 2016/1141 of 13 July 2016 adopting a list of invasive alien species of Union concern pursuant to Regulation (EU) No 1143/2014 of the European Parliament and of the Council, Official Journal of the European Union, L 189/4, 14 July 2016.

29. Ficetola G. F., Coïc C., Detaint M., Berroneau M., Lorvelec O. and Miaud C., 2007a - Pattern of distribution of the American bullfrog Rana catesbeiana in Europe, Biological Invasions, 9, 767-772.

30. Ficetola G. F., Rödder D. and Padoa-Schioppa E., 2012 - Trachemys scripta (Slider terrapin), in Handbook of global freshwater invasive species, in Francis R. (eds) Earthscan, Taylor and Francis Group Abingdon, UK, 331-339.

31. Ficetola G. F., Thuiller W. and Miaud C., 2007b - Prediction and validation of the potential global distribution of a problematic alien invasive species the American bullfrog, Diversity and Distributions, 13, 476-485.

32. Gavriloaie I. C., 2007 - Survey on the alien freshwater fish species entered into Romania's fauna, Acta Ichtiologica Romanica, II, 107-118.

33. Gavriloaie I. C. and Chiș I. E., 2006 - Considerations regarding the present situation of species Pseudorasbora parva (Temminck and Schlegel, 1846) (Pisces, Cyprinidae, Gobioninae) in Romania, Drobeta, Seria Ştiinţele Naturii, 16, 123-133. (in Romanian)

34. Gherardi F., 2007 - Understanding the impact of invasive crayfish. Biological invaders in inland waters: Profiles, distribution, and threats. F. Gherardi. Dordrecht, Springer Netherlands: 507-542.

35. Giurcă R. and Angelescu N., 1971 - Consideratins regarding the biology and geographical range of the cyprinid Pseudorasbora parva (Schlegel) in Romanian waters, Buletinul Institutului de Cercetări şi Proiectări Piscicole, 30, 3-4, 99-109. (in Romanian)

36. Goia I., Ciocanea C.-M. and Gavrilidis A.-A., 2014 - Geographic origins of invasive alien species in "Iron Gates” Natural Park (Banat, Romania), Transylvanian Review of Systematical and Ecological Research, 16, The "Iron Gates” Natural Park, 115-130.

37. Gomoiu M. T. and Skolka M., 1998 - Creșterea biodiversității prin imigrare - Noi specii în fauna României, Analele Universităţii “Ovidius” din Constanța, Seria Biologie-Ecologie, 2, 181-202. (in Romanian)

38. Hartel T., Öllerer K. and Moga C. I., 2007 - Regional distribution, dynamic and determinants of breeding pond pond use in Pelobates fuscus (Amphibia) in the middle section of the Târnava Mare Basin (Transylvania, Romania), Transylvanian Review of Systematical and Ecological Research, 2, The Târnava River Basin, 123-136.

39. Haxaire J., Bouguet J. P. and Tamisier J. P., 2006 - Vespa velutina Lepeletier, 1836, une redoutable nouveauté pour la faune de France (Hym., Vespidae), Bulletin de la Société entomologique de France, 111, 2, 194.

40. Herborg L. M., Rushton S. P., Clare A. S. and Bentley M. G. 2003 - Spread of the Chinese mitten crab (Eriocheir sinensis H. Milne Edwards) in continental Europe: analysis of a historical data set, Hydrobiologia, 503, 21-28.

41. Holčik J., 1991 - Fish introductions in Europe with particular reference to its central and eastern part, Canadian Journal of Fisheries and Aquatic Sciences, 48, S1, 13-23

42. Holdich D. M., 2002 - Distribution of crayfish in Europe and some adjoining countries, Bulletin Français de la Pêche et de la Pisciculture, 367, 4, 611-650.

43. Holdich D. M. and Black J., 2007 - The spiny-cheek crayfish, Orconectes limosus (Rafinesque, 1917), digs into the UK, Aquatic Invasions, 2, 1, 1-15.

44. Jelić L., Hutinec B. J. and Jelić D., 2016 - Reproductive biology of Trachemys scripta (Schoepff, 1792) in continental Croatia, Hrvatski simpozij o invazivnim vrstama/2nd Croatian Symposium on invasive species Zagreb, Croatia, 21-22, XI 2016, 36.

45. Jurajda P., Vassilev M., Polačik M. and Trichkova T., 2006 - A first record of Perccottus glenii in the Danube River in Bulgaria, Acta Zoologica Bulgarica, 58, 2, 279-282. 
46. Kati S., Mozsár A., Árva D., Cozma N. J., Czeglédi I., Antal L., Nagy S. A. and Erös T., 2015 - Feeding ecologyof the invasive Amur sleeper (Perccottus glenii Dybowski, 1877) in Central Europe, International Review of Hydrobiology, 100, 3-4, 116-128.

47. Kirbiš N., Bedjanič M., Veenvliet J. K., Veenvliet P., Stanković D., Lipovšek G. and Poboljšaj K., 2016 - First records of the American bullfrog Lithobates catesbeianus (Shaw, 1802) in Slovenia, Natura Sloveniae, 18, 23-27.

48. Koščo J., Manko P., Miklisová D. and Košuthová L., 2008 - Feeding ecology of invasive Perccottus glenii in Slovakia, Czech Journal of Animal Science, 53, 11, 479-486.

49. Kouba A., Petrusek A. and Kozák P., 2014 - Continental-wide distribution of crayfish species in Europe: update and maps, Knowledge and Management of Aquatic Ecosystems, 413, 05.

50. Kutsarov Y. and Trichkova T., 2016 - Chinese Mitten Crab in the Bulgarian Stretch of the Danube River, ESENIAS - East and South European Netwok for Invasive Alien Species. http://esenias.org/index.php?option=com_content\&task=view\&id=317

51. Kvach Y., 2012 - First record of the Chinese sleeper Perccottus glenii Dybowski, 1877 in the Ukrainian part of the Danube delta, BioInvasions Records, 1, 1, 25-28.

52. Lansdown R., Anastasiu P., Barina Z., Bazos I, Çakan H., Cakovic D., Delipetrou P., Matevski V., Mitic B., Ruprecht E., Tomovic G., Tosheva A. and Kiraly G., 2016 - Review of Alien Freshwater Vascular Plants in South-East Europe, 141-158, in Rat M., Trichkova T., Scalera R., Tomov R. and Uludag A. (eds) ESENIAS Report 2015 - State of the Art of Invasive Alien Species in South-Eastern Europe, publishers: University of Novi Sad Faculty of Sciences, Department of Biology and Ecology, Novi Sad, Serbia, East and South European Network for Invasive Alien Species, Sofia, Bulgaria, ISBN 978-86-7031-3316.

53. Lodge D. M., Stein R. A., Brown K. M., Covich A. P., Bronmark C., Garvey J. E. and Klosiewski S. P., 1998 - Predicting impact of freshwater exotic species on native biodiversity: challenges in spatial scaling, Australian Journal of Ecology, 23, 53-67.

54. Loureiro T. G., Anastácio S. G., Araujo P. B., Souty-Grosset C. and Almerão M. P., 2015 Red Swamp crayfish: biology, ecology and invasion - an overview, Nauplius, 23, 1-19.

55. Luca M. and Ghiorghiță G., 2014 - The invasive species Perccottus glenii - a threat for the fresh water ecosystems, Analele Ştiinţifice ale Universităţii „,Alexandru Ioan Cuza” din Iaşi, Seria Biologie Animală, I.X, 129-138.

56. Luca M., Ureche D., Nicuță D., Ghiorghiță G., Druică R. C. and Gorgan L. D., 2014 - The genetic variability of the invasive Perccottus glenii from Siret River, using the cytochrome $b$ gene, Annals of Romanian Society for Cell Biology, 19, 1, 11-20.

57. Maruşca T. and Pop O., 2001 - Heracleum sosnowskyi from Prejmer-Braşov, a new adventive species for Romanian Flora, Acta Horti Botanici Bucurestiensis, 29, 149-153.

58. Micu S. and Micu D., 2006 - Proposed IUCN Regional Status of all Crustacea: Decapoda from the Romanian Black Sea, Analele Ştiinţifice ale Universităţii „Alexandru Ioan Cuza” Iaşi, Seria Biologie Animală, LII, 7-38.

59. Ministerial Order 979/2009 privind introducerea de specii alohtone, intervențiile asupra speciilor invazive, precum și reintroducerea speciilor indigene prevăzute în anexele nr. 4A și 4B la Ordonanța de urgență a Guvernului nr. 57/2007 privind regimul ariilor naturale protejate, conservarea habitatelor naturale, a florei și faunei sălbatice, pe teritoriul naţional. Ministry of the Environment, Romania. (in Romanian)

60. Monceau K., Arca M., Leprêtre L., Mougel F., Bonnard O., Silvain J. F., Maher N., Arnold G. and Thiéry D., 2013 - Native Prey and Invasive Predator Patterns of Foraging Activity: The Case of the Yellow-Legged Hornet Predation at European Honeybee Hives, PLoS ONE, 8, 6, 1-9.

61. Moşu A., 2007 - Invazia în unele ecosisteme acvatice ale Republicii Moldova a peştelui alogen Percottus glenii Dybowski, 1877 (Perciformes: Odontobutidae), în Problemele Actuale ale Protecţiei şi Valorificării Durabile a Diversităţii Lumii Animale, 170-172. (in Romanian)

62. Moşu A. J., Davideanu G. G. and Cebanu A. S., 2006 - Elements on the ichtyofauna diversity of Prut River basin, Acta Ichtiologica Romanica, I, 171-184. 
63. Murariu D. and Chisamera G., 2004 - Myocastor coypus Molina, 1782 (Mammalia: Rodentia: Myocastoridae), A new report along the Danube River in Romania, Travaux du Museum National d'Histoire Naturelle “Grigore Antipa”, 46, 281-287.

64. Nalbant T., Battes K., Pricope F. and Ureche D., 2004 - First record of the Amur sleeper Perccottus glenii (Pisces: Perciformes: Odontobutidae) in Romania, Travaux du Musèum National d'Histoire Naturelle “Grigore Antipa”, 47, 279-284.

65. Năstase A., 2007 - First record of Amur sleeper Perccottus glenii (Pisces: Perciformes: Odontobutidae) in the Danube Delta (Dobrogea, Romania), Acta Ichtiologica Romanica, 2, 167-174.

66. Năvodaru I. and Năstase A., 2006 - Ichthyofauna of river Danube Delta: Gorgova - Uzlina and Şontea - Furtuna lakes complexes, Acta Ichtiologica Romanica, I, 185-202.

67. Novikov N. P., Sokolovsky A. S., Sokolovskaya T. G. and Yakovlev Y. M., 2002 - The fishes of Primorye, Vladivostok, Far Eastern State Technological Fisheries University, 552.

68. Oțel V., 2004 - The presence of Eriocheir sinensis Milne-Edwards, 1835 (Crustacea, Decapoda) in the Danube Delta Biosphere Reserve area, Analele Ştiinţifice ale Institutului de Cercetare şi Proiectare Delta Dunării Tulcea, 10, 45-48.

69. Oțel V., 2007 - Atlasul peștilor din Rezervația Biosferei Delta Dunării, Edit. Centrul de Informare Tehnologică Delta Dunării, Tulcea, 482. (in Romanian)

70. Paunovic M., Cakic P., Hegedis A., Kolarevic J. and Lenhardt M., 2004 - A report of Eriocheir sinensis (H. Milne Edwards, 1854) (Crustacea: Brachyura: Grapsidae) from the Serbian part of the Danube River, Hydrobiologia, 529, 275-277.

71. Pârvulescu L., Paloș C. and Molnar P., 2009 - First record of spiny-cheek crayfish Orconectes limosus (Rainesque, 1817) (Crustacea: Decapoda: Cambaridae), North-Western Journal of Zoology, 5, 2, 424-428.

72. Popa L. O, Popa O. P., Pisică E. I., Iftime A., Matacă S., Diaconu F. and Murariu D., 2006 The first record of Perccottus glenii Dybowski, 1877 (Pisces: Odontobutidae) and Ameiurus melas Rafinesque, 1820 (Pisces: Ictaluridae) from the Romanian sector of the Danube, Travaux du Muséum National d'Histoire Naturelle “Grigore Antipa”, 49, 323-329.

73. Puky M., Reynolds J. D. and Schád P., 2005 - Native and alien decapoda species in Hungary: Distribution, status, conservation importance, Bulletin Français de la Pêche et de la Pisciculture, 376-377, 553-568.

74. Rome Q., Perrard A., Muller F. and Villemant C., 2011 - Monitoring and control modalities of a honeybee predator, the yellowlegged hornet Vespa velutina nigrithorax (Hymenoptera: Vespidae), Aliens: The Invasive Species Bulletin, 31, 7-15.

75. Rudnick D. and Resh V., 2005 - Stable isotopes, mesocosms and gut content analysis demonstrate trophic differences in two invasive decapod crustacean, Freshwater Biology, 50, 1323-1336.

76. Schiemer F., Guti G., Keckeis H. and Staraş M., 2004 - Ecological status and problems of the Danube River and its fish fauna: a review, Proceedings of the second International Symposium on the Management of Large Rivers for Fisheries, I, Sustaining livelihoods and biodiversity in the new millennium, RAP Publication (FAO), 16, 273-299.

77. Schrimpf A., Pârvulescu L., Copilaş-Ciocianu D., Petrusek A. and Schulz R., 2012 - Crayfish plague pathogen detected in the Danube Delta - a potential threat to freshwater biodiversity in southeastern Europe, Aquatic Invasions, 7, 4, 503-510.

78. Schrimpf A., Schmidt T. and Schulz R., 2014 - Invasive Chinese mitten crab transmits crayfish plague pathogen (Aphanomyces astaci), Aquatic Invasions, 9, 2, 203-209.

79. Simonović P., Marić S. and Nikolić V., 2006 - Record of the Amur sleeper Perccottus glenii in Serbia and its recent status, Archives of Biological Science, Belgrade, 58, 1, 7-8.

80. Sîrbu C. and Oprea A., 2011 - Plante adventive în Flora României, Iași, Edit. ”Ion Ionescu de la Brad”, 733. (in Romanian) 
81. Škraba D., Tošić A., Miličić D., Nikolić V. and Simonović P., 2013 - Invasiveness assessment of the Chinese mitten crab Eriocheir sinensis (H. Milne Edwar ds, 1853) in the Serbian section of the river Danube, Archives Biological Sciences, 65, 1, Belgrade, 353-358.

82. Souty-Grosset C., Anastácio P. M., Aquilonic L., Banhab F., Choquera J., Chucholld C. and Tricarico E., 2016 - The red swamp crayfish Procambarus clarkii in Europe: Impacts on aquatic ecosystems and human well-being, Limnologica, 58, 78-93.

83. Strahm W. and Rietbergen S, 2001 - Alien invasions from our own planet, IUCN European Programme Newsletter, 27, September, Praha. 3.

84. Stumpel A. H., 1992 - Successful reproduction of introduced bullfrogs in northwestern Europe: a potential threat to indigenous amphibians, Biological Conservation, 60, 1, 61-62.

85. Takács P., Czeglédi I., Ferincz Á., Sály P., Specziár A., Vitál Z., Weiperth A. and Erös T., 2017 - Non-native fish species in Hungarian waters: historical overview, potential sources and recent trends in their distribution, Hydrobiologia, 795, 1-22, DOI: 10.1007/s10750-017-3147$\mathrm{x}$.

86. Telcean I. and Cupşa D., 2009 - The backwaters and drainage canals as natural refuges for the lowland rivers' fishfauna (Someş, Crişuri, and Mureș Rivers - north-western Romania), Biharean Biologist, 3, 1, 37-44.

87. Telcean I. C. and Cicort-Lucaciu A.-Ş., 2016 - Messages of invasive Perccottus glenii individuals eaten by an Esox lucius from the Danube Delta, Journal of Fisheries, 4, 3, 435438, DOI: dx.doi.org/10.17017/jfish.v4i3.2016.190.

88. Țopa E., 1955 - Family 33, Nymphaeaceae DC, 34-49, in Săvulescu T. Flora Romaniae, 3, Edit Academiei Române, 664. (in Romanian)

89. Uotila P., 2009 - Cabombaceae, in: Euro+Med Plantbase - the information resource for EuroMediterranean plant diversity, available at: http://ww2.bgbm.org/EuroPlusMed/PTaxon Detail.asp?NameCache=Cabomba\%20caroliniana\&PTRefFk=7300000 (12 March 2017).

90. Ureche D. and Ureche C., 2015 - Research regarding the fish communities in Bahna, Topolniţa, and Blahniţa (Danube tributaries, Romania), Scientific Study and Research Biology, 24, 2, 67-72.

91. Vamberger M., Lipovšek G. and Gregorič M., 2012 - First reproduction record of Trachemys scripta (Schoefpp, 1792), Slovenia, Herpetozoa, 25, 76-79.

92. Verreycken H., Van Thuyne G. and Belpaire C., 2011 - Length-weight relationships of 40 freshwater fish species from two decades of monitoring in Flanders (Belgium), Journal of Applied Ichthyology, 2011, 1-5.

93. Vornicu B., Davideanu G. and Davideanu A., 2006 - Data concerning the fish communities of the Moldova River (Romania), Acta Ichtiologica Romanica, I, 293-304.

94. Welcomme R. L., 1988 - International introductions of inland aquatic species, FAO Fish Technical Paper, 294, 318.

95. Witkowski A., 2009 - On the expansion and occurrence of an invasive species Pseudorasbora parva (Temminck et Schlegel, 1846) (Teleostei: Cyprinidae: Gobioninae) in Poland, Fragmenta Faunistica, 52, 1, 25-32. Wittenberg

96. Woods C., Contreras L., Willner-Chapmen G. and Whidden H., 1992 - Myocastor coypus, Mammalian Species, 398, 1-8.

97. $* * *$ CABI ISC - web page address

98. ***DAISIE

99. ***ESENIAS

100. ***GISD - Global Invasive Species Database http://www.iucngisd.org/gisd/ 